\title{
DETECTION OF MONOSOMY 7 BY FLUORESCENCE IN SITU HYBRIDIZATION IN ACUTE NONLYMPHOCYTIC LEUKEMIA AND MYELODYSPLASTIC SYNDROME
}

\author{
Hitoshi NaKagawa \\ Third Department of Medicine, Kyoto Prefectural University of Medicine, \\ Kawaramachi-Hirokoji, Kamigyo-ku, Kyoto 602, Japan
}

\begin{abstract}
Summary Fluorescence in situ hybridization (FISH) with a chromosome 7 specific alpha satellite DNA probe was used to detect monosomy 7 in interphase and metaphase cells obtained from patients with myelodysplastic syndrome (MDS) and acute nonlymphocytic leukemia (ANLL). Chromosome analysis revealed monosomy 7 , either alone or as part of a complex chromosome abnormality, in all cell samples. FISH analyses of 12 marrow samples and a blood sample using a chromosome 7 specific alpha satellite DNA probe revealed a single fluorescence spot in $80.5-97.5 \%$ of interphase cells indicating monosomy 7. In contrast, $83.5-92.0 \%$ of the same cells had two copies of chromosome 17 as two fluorescent spots were detected using a chromosome 17 specific alpha satellite DNA probe used as a positive control. The proportion of interphase cells with monosomy 7 did not correlated with the percentage of metaphase cells with monosomy 7 detected by conventional karyotyping or with the percentage of blast cells in the bone marrow.
\end{abstract}

Key Words monosomy 7, fluorescence in situ hybridization, myelodysplastic syndrome, acute nonlymphocytic leukemia

\section{INTRODUCTION}

Monosomy 7 is found as a single abnormal change or in association with complex chromosome abnormalities in patients with de novo acute nonlymphocytic leukemia (ANLL), therapy related leukemia, and myelodysplastic syndrome (MDS) (Sandberg, 1990). Previous studies revealed that monosomy 7 correlated with a poor prognosis in these patients (Rowley et al., 1981; Le Beau et al., 1986; Horiike et al., 1988; Shiffer et al., 1989).

Monosomy 7 can be detected in neoplastic cells by cytogenetic analysis of

Received April 13, 1993; Revised version accepted July 19, 1993. 
metaphase chromosomes. However, this method is limited to the study of metaphase cells, representative of mitotic cells, and not of all cells present in short-term cultures. Fluorescence in situ hybridization (FISH) using chromosome specific alpha satellite DNA probes has made it possible to detect numerical chromosome aberrations in interphase as well as metaphase cells. The satellite DNA probes recognize the centromeric region of each chromosome, thereby identifying numerical chromosome alterations in tumor cells (Cremmer et al., 1988; Nederlof et al., 1989; Dekken et al., 1989; Poddighe et al., 1991).

FISH was performed using a chromosome 7 specific alpha satellite DNA probe in six patients with MDS and three with ANLL. The results of FISH on interphase cells showed that a large population of cells had been replaced by a monosomy 7 clone, regardless of the proportion of blast cells at the time of diagnosis. Four MDS patients progressed to ANLL and incidence of monosomy 7 during the two phases of their disease was compared.

\section{MATERIALS AND METHODS}

Patients. Six patients with MDS and three with de novo ANLL were selected; all patients had cells with monosomy 7 and some had other complex chromosome aberrations as detected by ordinary karyotype analysis. Diagnosis was made according to the FAB criteria (Bennett et al., 1976, 1982), and clinical data regarding these patients are summarized in Table 1. Four of the six MDS patients progressed to ANLL, and samples from the leukemic phase were also examined.

Chromosome analysis. Bone marrow cells were obtained from all patients with the exception of patient 9, from whom peripheral blood was obtained. Cells were cultured in RPMI 1640 with $15 \%$ fetal bovine serum for $24 \mathrm{hr}$ at $37^{\circ} \mathrm{C}$ without mitogen and treated with colcemid for the last $1 \mathrm{hr}$ of culture. Chromosome preparations were made according to standard procedures including treatment with a hypotonic solution and fixation with a methanol/acetic acid mixture (3:1). Chromosomes on slide glasses were banded by the trypsin-Giemsa method (Whang and Federoff, 1972). Well spread metaphase cells were photographed and karyotyped according to the International System for Cytogenetic Nomenclature (1991). A culture of lymphocytes from a normal female stimulated with phytohemagglutinin was used as a control. After chromosome preparations were made, the remainder of the cells were stored at $-20^{\circ} \mathrm{C}$ in the same fixative.

Fluorescent in situ hybridization (FISH). Preparations were made from preserved materials in the same manner used for chromosome analysis. The slides were treated with protenase $\mathrm{K}(60 \mu \mathrm{g} / \mathrm{ml}$ in $\mathrm{PBS}, \mathrm{pH} 7.0)$ at $37^{\circ} \mathrm{C}$ for $7 \mathrm{~min}$. After removal of protenase $\mathrm{K}$ in PBS, slides were dehydrated in 70, 90, and $100 \%$ ethanol. Chromosome DNA was then denatured in $70 \%$ formamide in $2 \times$ SSC at $70^{\circ} \mathrm{C}$ for $90 \mathrm{sec}$, dehydrated again in ethanol at $4{ }^{\circ} \mathrm{C}$ and dried.

Biotinylated chromosome specific alpha satellite DNA probes, p7t1 for chro- 
mosome 7 and p17H8 for chromosome 17, were purchased from Oncor, USA. The p17H8 was used as a positive control. These probes were dissolved in formamide and denatured at $75^{\circ} \mathrm{C}$ for $10 \mathrm{~min}$. In situ hybridization was performed according to the method previously described (Laurence et al., 1988; Takahashi et al., 1989) with modifications. Twenty microliters of hybridization buffer $(50 \%$ formamide, $2 \times \mathrm{SSC}, 400 \mu \mathrm{g} / \mathrm{ml}$ of salmon sperm DNA, $400 \mu \mathrm{g} / \mathrm{ml}$ of $E$. coli tRNA, and $10 \%$ dextran sulfate) containing $100 \mathrm{ng} / \mathrm{ml}$ of probe were placed on the slides, covered with parafilm, and incubated in a humidified chamber at $42^{\circ} \mathrm{C}$ for $10-16 \mathrm{hr}$. The slides were washed for $15 \mathrm{~min}$ in each of the following buffers; $50 \%$ formamide in $2 \times \mathrm{SSC}, 2 \times \mathrm{SSC}$, and $1 \times \mathrm{SSC}$. Slides were washed at $45^{\circ} \mathrm{C}$ following incubation with the $\mathrm{p} 7 \mathrm{t} 1$ probe and at $48^{\circ} \mathrm{C}$ for the $\mathrm{p} 17 \mathrm{H} 8$ probe. Fluorescent signals were amplified as previously described with biotinylated goat anti-avidin antibody and fluorescein-avidin DCS (Pinkel et al., 1986; Nakagawa et al., 1992). The slides were then counter-stained with propidium iodide and mounted in antifade agent.

The number of fluorescent spots in each nucleus was counted under a fluorescence microscope with a filter combination Nikon B2-A according to reported methods (Cremmer et al., 1988; Nederlof et al., 1989; Dekken et al., 1989). Two hundred single round nuclei were counted; not including cell clusters, broken cells, metaphase cells or cells with very weak or irregularly shaped signals.

\section{RESULTS}

\section{Chromosome analysis}

The results of chromosome analysis are summarized in Table 1. Monosomy 7 was found in all patients in greater than $50 \%$ of the metaphase cells analyzed. In five patients, monosomy 7 was either the sole abnormality or was associated with only one other anomaly. In four patients, the karyotypes were complex, and monosomy 7 was detected as one of the abnormalities. In patients $1-4$, chromosome analysis was performed at the MDS and terminal leukemic phases. The population of cells with monosomy 7 increased in the leukemic phase in patient 4 , disappeared in patient 2 (in whom only two mitotic cells were available for karyotyping), and remained essentially unchanged in patients 1 and 3 .

\section{FISH}

In a control sample of PHA stimulated lymphocytes, 92 and $90 \%$ of interphase cells exhibited two fluorescent spots when hybridized to $\mathrm{p} 7 \mathrm{t} 1$ and $\mathrm{p} 17 \mathrm{H} 8$, respectively (Table 2). Representative metaphase and interphase cells are shown in Fig. 1.

Results of FISH in nine patients are summarized in Table 2. Following hybridization with the chromosome 7 specific $\mathrm{p} 7 \mathrm{t} 1$ probe, a single fluorescent spot was observed in 70.5 to $97.5 \%$ of 200 interphase cells examined from each patient. In contrast, a single spot was detected in only 7.0 to $13.0 \%$ of cells probed with 


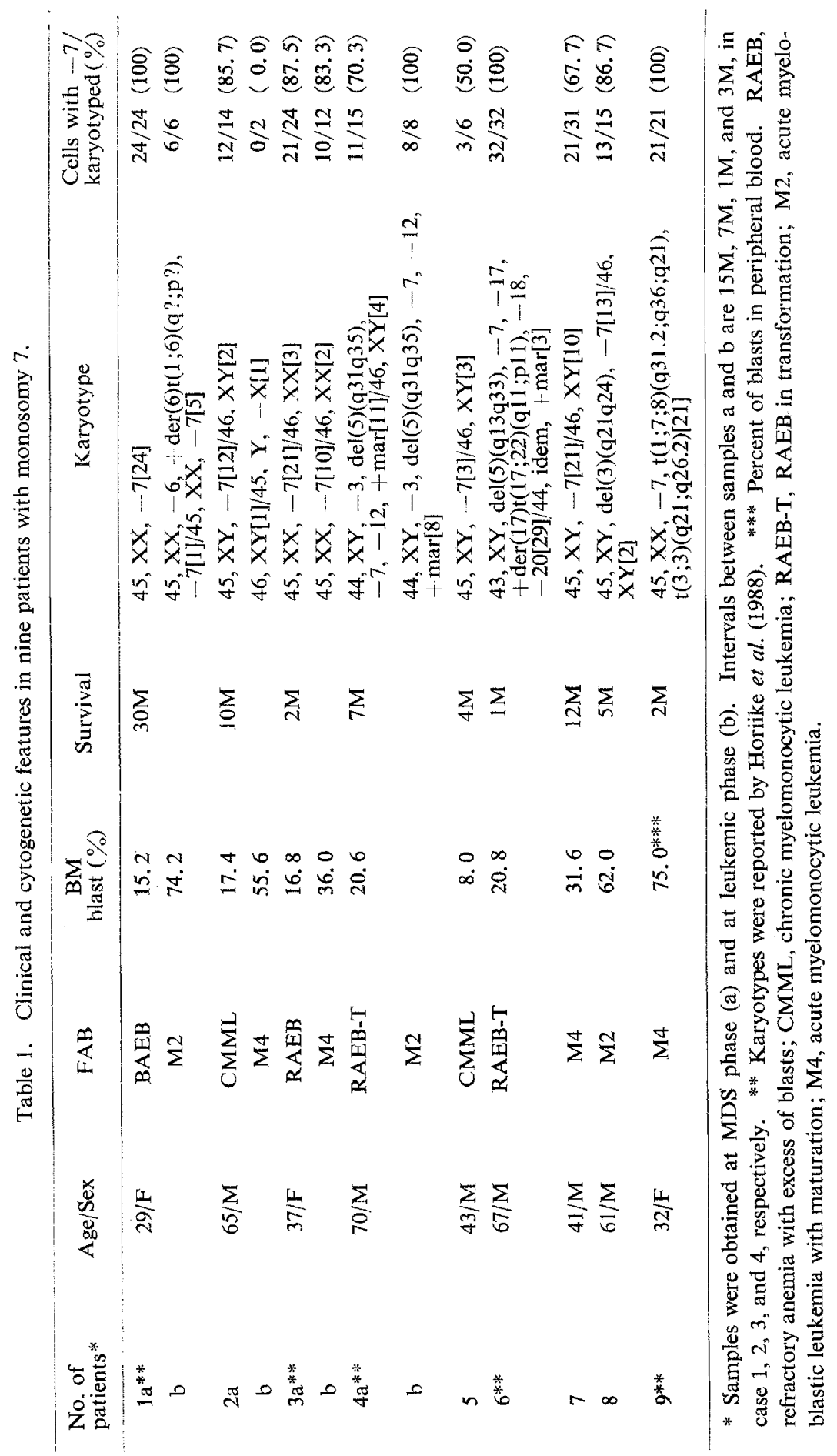


Table 2. Number of fluorescent spots detected in control lymphocytes, MDS and ANLL interphase cells hybridized with chromosome specific biotinylated probes.

\begin{tabular}{|c|c|c|c|c|c|c|c|c|}
\hline \multirow{2}{*}{ Patient No. } & \multicolumn{4}{|c|}{ Chromosome $7^{*}$} & \multicolumn{4}{|c|}{ Chromosome $17^{*}$} \\
\hline & 1 & 2 & 3 & $\geq 4$ & 1 & 2 & 3 & $\geq 4$ \\
\hline Control & 7.0 & 92.0 & 0.0 & 1.0 & 8.0 & 90.0 & 1.0 & 1.0 \\
\hline la & 70.5 & 28.5 & 0.5 & 0.5 & 10.0 & 86.0 & 2.5 & 1.5 \\
\hline$b$ & 83.0 & 16.5 & 0.0 & 0.5 & 7.0 & 92.0 & 1.0 & 0.0 \\
\hline $2 a$ & 81.0 & 16.0 & 2.0 & 1.0 & 10.0 & 86.0 & 2.5 & 1.5 \\
\hline$b$ & 81.0 & 18.0 & 0.5 & 0.5 & 13.0 & 84.0 & 2.0 & 1.0 \\
\hline $3 a$ & 83.0 & 17.0 & 0.0 & 0.0 & 13.0 & 84.0 & 2.0 & 1.0 \\
\hline $\mathrm{b}$ & 97.5 & 2.5 & 0.0 & 0.0 & 9.5 & 90.0 & 0.0 & 0.5 \\
\hline $4 a$ & 77.5 & 21.0 & 0.5 & 1.0 & 10.0 & 86.0 & 3.0 & 1.0 \\
\hline $\mathrm{b}$ & 95.0 & 5.0 & 0.0 & 0.0 & 11.0 & 86.0 & 1.5 & 1.0 \\
\hline 5 & 89.5 & 10.0 & 0.5 & 0.0 & 13.0 & 85.0 & 1.0 & 1.0 \\
\hline 6 & 88.5 & 11.5 & 0.0 & 0.0 & 7.0 & 83.5 & 2.0 & 2.5 \\
\hline 7 & 90.0 & 10.0 & 0.0 & 0.0 & 9.0 & 89.5 & 0.5 & 1.0 \\
\hline 8 & 92.0 & 8.0 & 0.0 & 0.0 & 11.0 & 88.5 & 0.5 & 0.0 \\
\hline 9 & 70.5 & 29.5 & 0.0 & 0.0 & 13.0 & 86.0 & 1.0 & 0.0 \\
\hline
\end{tabular}

* Numerals represent number of fluorescent spots. a, Samples obtained at MDS phase. $b$, Samples at terminal leukemic phase. Numbers of fluorescent spots are expressed as a percentage of the 200 cells analyzed in each group.

the chromosome 17 specific p17H8 DNA (Fig. 2). In patients 1, 3, and 4, there were fewer cells with a single spot in MDS phase as compared to the leukemic phase; from 70.5 to $83.0 \%, 83.0$ to $97.5 \%$, and 77.5 to $90.0 \%$, respectively (Statistically significant with Chi square test, $\mathrm{p}<0.05$ ). In patients 2 and 5 , we noticed only one signal on polymorphonuclear cells or monocytes determined from the shape of the nuclei using p7t1 (Fig. 3).

\section{DISCUSSION}

Acquired loss of chromosome 7 has frequently been found in patients with MDS and ANLL (Le Beau et al., 1986). This chromosome abnormality can be detected either as the sole cytogenetic abnormality or in association with trisomy 8, whole or partial monosomy 5, or other complex abnormalities (Sandberg, 1990). The prognosis of all patients with monosomy 7 is uniformly poor and most patients die of leukemia or related complications within months to a few years (Yunis et al., 1986a, b).

Nine patients with ANLL or MDS were studied, who exhibited monosomy 7 in 50 to $100 \%$ of metaphase cells karyotyped by routine chromosome analysis. Then, FISH was utilized with a chromosome 7 specific alpha satellite DNA probe 

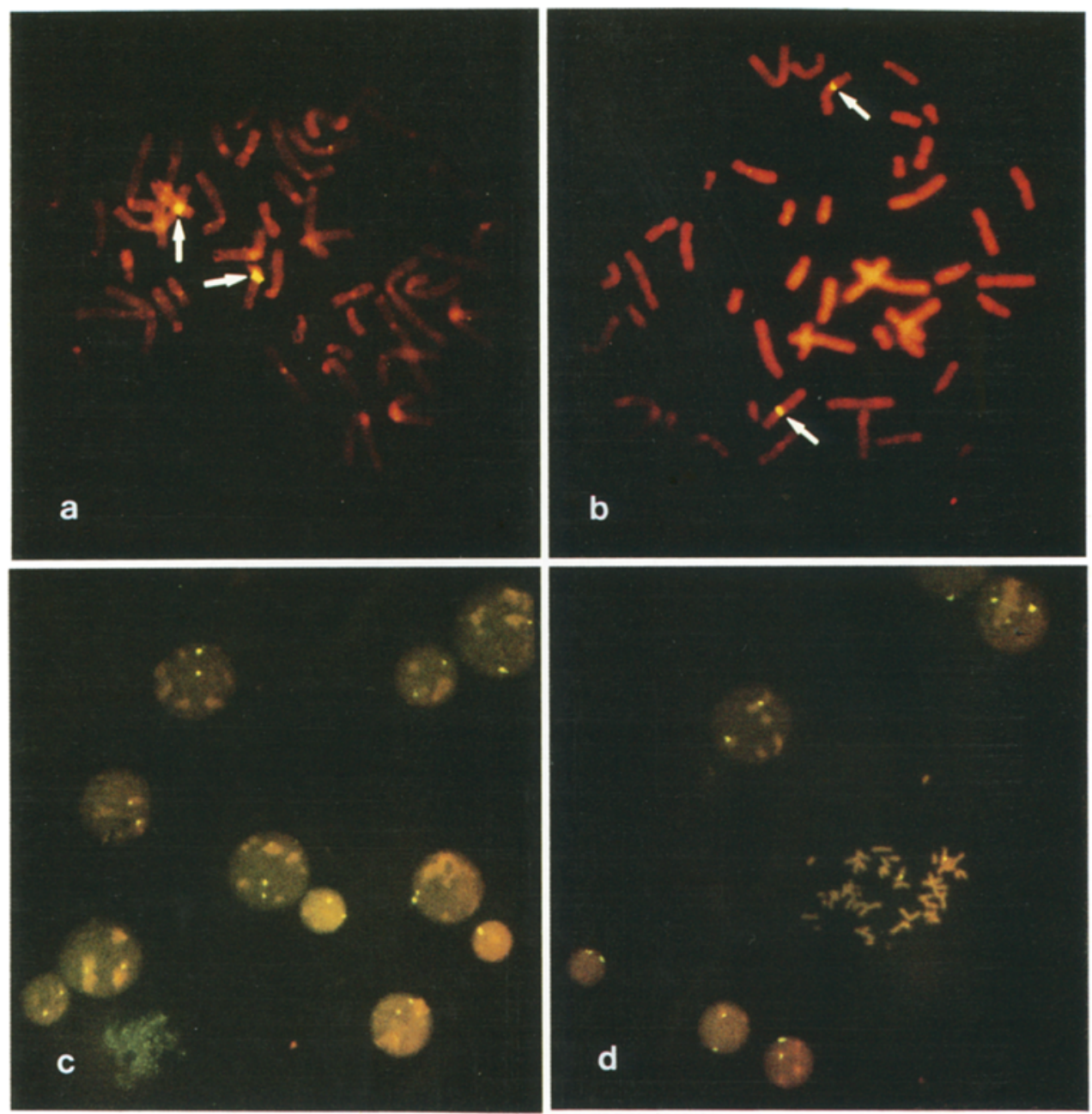

Fig. 1. Results of FISH with p17H8 $(a, c)$ and $p 7 t 1(b, d)$ probes on metaphase and interphase cells obtained from PHA-stimulated lymphocyte culture. Arrows indicate fluorescent spots at centromeric lesions of chromosome 17 and 7 on a metaphase cell, respectively $(a, b)$. Two fluorescent spots are shown in the majority of interphase nuclei (c, d).

Fig. 2. FISH of patient 7 reveals one fluorescent spot in $90 \%$ of interphase cells hybridized with p $7 t 1$ (a) and two fluorescent spots in $89.5 \%$ of cells hybridized with p17H8 (b).

Fig. 3. A metaphase and two interphase cells from a CMML patient (patient 2) showing a fluorescent spot with p7t1 (a). Polymorphonuclear granulocytes or monocytes of the same patient also exhibit one signal with p7tl (b) (filter combination Nikon B2-E). 


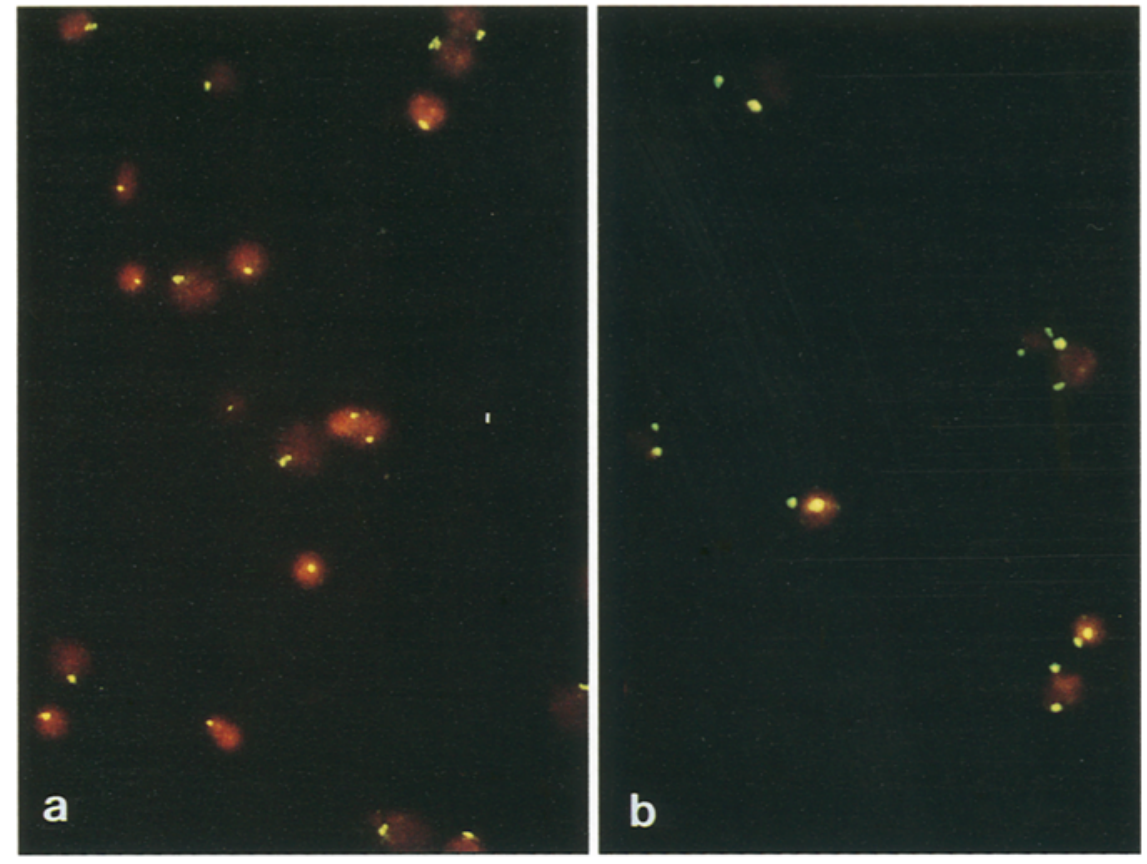

Fig. 2.

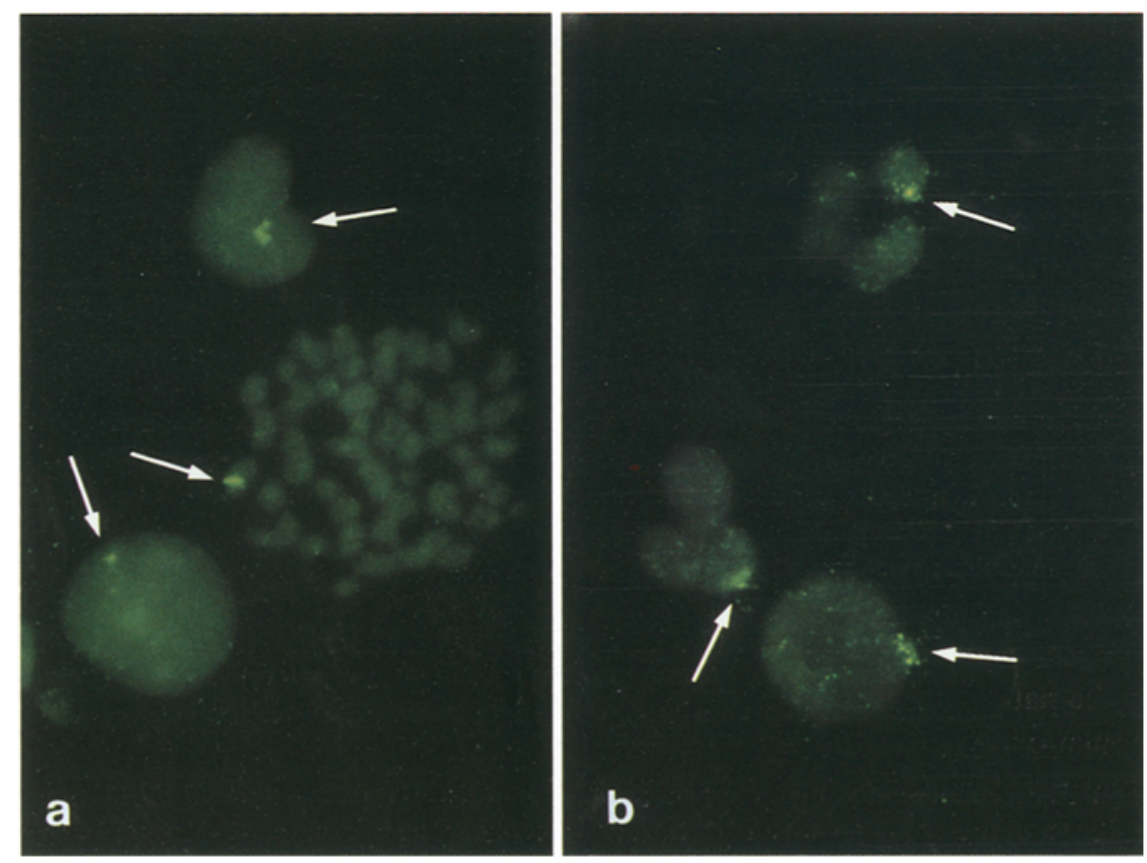

Fig. 3.

Vol. 38, No. 3, 1993 
p7t1 to detect monosomy 7 in interphase cells. A single fluorescent spot confirms the diagnosis of monosomy 7 , and $70-90 \%$ of cells from all patients were positive for a single fluorescent spot. A chromosome 17 alpha satellite probe was used as a positive control in FISH analysis and two fluorescent spots, indicative of two intact centromeric regions of chromosome 17 , were detected in greater than $84 \%$ of interphase cells examined from all patients. In contrast, interphase cells obtained from normal lymphocytes were positive for two fluorescent spots in greater than $90 \%$ of cells following hybridization with both the p7t1 and $\mathrm{p} 17 \mathrm{H} 8$ probes.

High stringency condition was employed in order to minimize cross-hybridization of the probes to other alpha satellite DNA families. Fluorescent signals were amplified by biotinylated anti avidin and fluorescein-avidin DCS. A reduced signal is hypothesized to be due to misintegration of the probe or overlapping of two different signals on the same plate. Additionally, in the absence of stringent conditions, cross-hybridization of the probe to homologous alpha satellite DNA might increase the number of fluorescent spots detected (Nederlof et al., 1989). Similar findings have been reported by other investigators who performed FISH with chromosome specific DNA probes (Dekken et al., 1989; Kiechle-Schwarts et al., 1991; Poddighe et al., 1991).

The proportion of monosomy 7 cells detected with FISH did not correlate with that in routine karyotypic analysis in our 13 samples $(r=-0.17)$. Since FISH is used to analyze interphase cells and karyotyping is performed on metaphase cells, it is possible that the proportion of monosomy 7 cells differs in these populations. However, the number of cells analyzed by karyotyping may be too small to be conclusive; less than ten metaphases were karyotyped in four samples. In a sample from the leukemic phase of patient 2, only two mitoses were karyotyped and monosomy 7 could not be detected. We utilized FISH on 200 bone marrow cells from this patient, and monosomy 7 was present in a large proportion of the cells. In such cases, conclusive cytogenetic information can only be obtained by performing interphase cytogenetics.

The proportion of myeloblasts in bone marrow smears varied from 8.0 to $74.2 \%$ among the samples examined. Monosomy 7 cells was detected in greater than $70 \%$ of the cells examined with FISH regardless of the percent blasts in the sample. These results indicate that a replacement of bone marrow cells with monosomy 7 cells is independent of the percentage of blast cells. In two chronic myelomonocytic leukemia patients, one fluorescent spot was observed with the chromosome 7 specific probe in mature neutrophils and monocytes (Fig. 3).

In the patients who progressed from the MDS to leukemia stage of their disease, the population of interphase cells with monosomy 7 tended to increase. Monosomy 7 clones existed in the morphological blast cell population as well as differentiated cells. Kere et al. (1987) detected a loss of hetelozygosity of the chromosome 7 genome in granulocytes and monocytes of MDS patients. Tachibana et al. (1988) reported that the monosomy 7 genotype was detected in erythroid as well as gran- 
ulocyte/macrophage progenitors in patients with MDS using the colony assay technique. Thus, the target cell of clonal neoplastic change is hypothesized to be a primitive hemopoietic progenitor cell capable of differentiating into granulocyte/ monocyte, erythrocyte, and megakaryocyte lineages (Michiels et al., 1986).

FISH allowed a more sensitive and specific analysis of interphase chromosome than conventional karyotype technique (Jenkins et al., 1992). The use of FISH may also enable the detection of a residual monosomy 7 cell clone in ANLL and MDS patients who have achieved complete remissions. Thus, this tool may provide information which can be invaluable in assessing the efficacy of various chemotherapies.

Acknowledgments I appreciate constructive advice of Profs. K. Kashima and T. Abe, and Drs. J. Inazawa, S. Misawa, and S. Horiike. This work was supported in part by Grant-in-Aid from the Ministry of Education, Science and Culture of Japan.

\section{REFERENCES}

Bennett JM, Catovsky D, Daniel MT, Flandarin G, Galton DAG, Gralnick HR, Sultan C (FAB Co-operative group) (1976): Proposals for the classification of the acute leukemias. Br J Haematol 33: $451-458$

Bennett JM, Catovsky D, Daniel MT, Flandarin G, Galton D, Gralnic H, Sultan C (FAB Cooperative Group) (1982): Proposals for the classification of the myelodysplastic syndromes. Br J Haematol 51: 189-199

Cremmer T, Landegent J, Bruckner A, Scholl HP, Shadin M, Hager HD, Devilee P, Pearson P, van der Ploeg M (1988): Detection of chromosome aberrations in the human interphase nucleus by visualization of specific target DNAs with radioactive and non-radioactive in situ hybridization techniques: diagnosis of trisomy 18 with probe. Hum Genet 74: 346-352

Dekken H, Hagenbeek A, Bauman JG (1989): Detection of host cells following sex mismatched bone marrow transplantation by fluorescent in situ hybridization with a Y-chromosome specific probe. Leukemia (Baltimore) 3: 724-728

Horiike S, Taniwaki M, Misawa S, Abe Y (1988): Chromosome abnormalities and karyotypic evolution in 83 patients with myelodysplastic syndrome and predictive value for prognosis. Cancer 62: 1129-1138

ISCN (1991): Guidelines for cancer cytogenetics. Supplement to an international system for human cytogenetic nomenclature. Mitelman F (ed). Karger, Basel

Jenkins EB, Le Beau MM, Kraker WJ, Borell TJ, Stalboerger PG, Davis EM, Penland L, Fernald A, Espinosa R III, Schaid DJ, Noel P, Dewald GW (1992): Fluorescence in situ hybridization: a sensitive method for trisomy 8 detection in bone marrow specimens. Blood 79: 33073315

Kere J, Ruutu T, de la Chapeile A (1987): Monosomy 7 in granulocytes and monocytes in myelodysplastic syndrome. N Engl J Med 316: 499-503

Kiechle-Schwartz M, Decker H, Berger CS, Fiebig HH, Sandberg AA (1991): Detection of monosomy in interphase nuclei and identification of marker chromosomes using biotinylated alphasatellite DNA probes. Cancer Genet Cytogenet 51: 23-33

Laurence JB, Villnave, Singer RH (1988): Sensitive, high-resolution chromatin and chromosome mapping in situ: presence and orientation of two closely integrated copies of EBV in a lymphoma line. Cell 52: 51-61

Le Beau MM, Albain KS, Larson RA, Vardiman JW, Davis EM, Blough RR, Golomb HM, Rowley

Vol. 38, No. 3, 1993 
JD (1986): Clinical and cytogenetic correlations in 63 patients with therapy-related myelodysplastic syndromes and acute nonlymphocytic leukemia: further evidence for characteristic abnormalities No. 5 and 7. J Clin One 4: 325-345

Michiels JJ, Mallios-Zorbala H, Prins MEF, Hahlen K, Hagemeijer A (1986): Simple monosomy 7 and myelodysplastic syndrome in thirteen patients without previous cytostatic treatment. Br J Haematol 64: 425-433

Nakagawa H, Inazawa J, Misawa S, Tanaka S, Takashima T, Taniwaki M, Abe T, Kashima $\mathrm{K}$ (1992): Detection of an $\mathrm{i}(17 \mathrm{q})$ in CML with fluorescent in situ hybridization using a chromosome 17 specific alpha satellite DNA probe. Cancer Genet Cytogenet 62: 140-143

Nederlof PM, van der Flier S, Raap AK, Tanke HJ, van de Ploeg M, Kornips F, Geraedts JPM (1989): Detection of chromosome aberrations in interphase tumor nuclei by non-radioactive in situ hybridization. Cancer Genet Cytogenet 42: 87-98

Pinkel D, Straume T, Gray JW (1986): Cytogenetic analysis using quantitive, high sensitivity, fluorescence hybridization. Proc Natl Acad Sci USA 83: 2934-2938

Poddighe PJ, Moesker O, Smeets D, Awwad BH, Ramaekers FC, Hopman AH (1991): Interphase cytogenetics of hematological cancer: comparison of classical karyotyping and in situ hybridization using a panel of eleven chromosome specific DNA probes. Cancer Res 51: 1959-1967

Rowley JD, Golomb HM, Vardiman JW (1981): Nonrandom chromosome abnormalities in acute leukemia and dysmyelopoietic syndrome patients with previously treated malignant disease. Blood 58: 759-767

Sandberg AA (1990): The chromosome in human cancer (2nd ed.), Elsevier, New York

Shiffer CA, Lee EJ, Tomiyasu T, Wiernik PH, Testa JR (1989): Prognostic impact of cytogenetic abnormalities in patients with de novo acute nonlymphocytic leukemia. Blood 73: 263-270

Tachibana N, Raimondi SC, Santana VM, Dow LW (1988): Cytogenetic evidence for involvement of erythroid and granulocyte/macrophage progenitors in an infant with monosomy 7 syndrome presenting de novo. Med Pediatr Oncol 16: 118-122

Takahashi E, Hori T, Laurence JB, McNeil J, Singer RH, O'Connell P, Leppert M, White R (1989): Human type II collagen gene (COL2AI) assigned to chromosome 12q31.1-q13.2 by in situ hybridization with biotinylated DNA probe. Jpn J Human Genet 34: 307-311

Whang HC, Federoff S (1972): Banding in human chromosomes treated with trypsin. Nature New Biol 235: $52-54$

Yunis JJ, Brunning RD (1986́a): Prognostic significance of chromosomal abnormalities in acute leukemias and myelodysplastic syndrome. Clin Haematol 15: 597-620

Yunis JJ, Rydell RE, Oken MM, Arnesen MA, Mayer MG, Lobell M (1986b): Refined chromosome analysis as an independent prognostic indicator in de novo myelodysplastic syndromes. Blood 67: $1721-1730$ 